\title{
Relationships between scores on Stanford-Binet IV and scores on McCarthy Scales of Children's Abilities
}

\author{
HOWARD CARVAJAL, SHARON K. KARR, KATHLEEN M. HARDY, \\ and BETTYE L. PALMER \\ Emporia State University, Emporia, Kansas
}

(Stephen F. Davis, Sponsor)

\begin{abstract}
A kindergarten class of 10 boys and 11 girls took the 1986 Stanford-Binet Intelligence Scale (4th ed.) and the McCarthy Scales of Children's Abilities. The correlation of total scores was statistically significant $(p<.001)$.
\end{abstract}

The 1986 Stanford-Binet Intelligence Scale (4th ed.; Binet IV) was designed to appraise the cognitive skills of children as young as age 2 . The McCarthy Scales of Children's Abilities (MSCA) were designed to assess the general intellectual level of children from age $2 \frac{1}{2}$ to age $81 / 2$. According to Salvia and Ysseldyke (1985, p. 171), "It is only a matter of time before the MSCA becomes one of the most popular tests for assessing the abilities of preschool children. The tasks are interesting and enjoyable; the directions are clear; the standardization and reliability are excellent." Because the technical manual for the Binet IV gives data only about the relationships of the Binet IV with the Wechsler series and with the Kaufman Assessment Battery for Children, this study was undertaken to supply preliminary information about the relationship of the Binet IV composite standard age scores (SAS) with the MSCA general cognitive scores (GCS).

\section{METHOD}

\section{Subjects}

A regular kindergarten class of 21 children ( 10 boys, 11 girls) from a midwest community of 27,000 was given both tests. The children's mean age was 5 years, 9 months $(S D=4.6$ months; range $=5,2$ to 7,0 ). The children were from middleclass families; 1 boy was black, and 1 girl was Hispanic.

\section{Procedure}

The complete battery (eight subtests) of the Binet IV $(M=100, S D$ $=16$ ) was given, and those subtests that make up the general cognitive area of the MSCA $(M=100, S D=16)$ were also given. Testing was conducted between $1: 30$ and 3:30 p.m. in rooms that were specifically designed and equipped for testing. The tests were administered in a counterbalanced sequence. One examiner gave the Binet IV, and another gave the MSCA. The examiners were graduate school psychology students, and each had completed successfully the graduate course in the specific test that each was administering.

Address correspondence to Howard Carvajal, Department of Psychology, Emporia State University, i200 Commercial, Emporia, KS 66801-5087.

\section{RESULTS}

For the children, the Binet IV mean composite SAS was $113.4(S D=11.8)$, and the MSCA mean GCS was 112.0 $(S D=13.7)$. There were no significant differences between male and female means or between the Binet IV and the MSCA means. The correlation between the Binet IV and the MSCA composite scores was .68 $(p<.001, d f=19)$.

\section{DISCUSSION}

The Binet IV-MSCA correlation of .68 is slightly lower than the correlation of .81 between the third edition of the Stanford-Binet and the MSCA for 35 white children (ages 6-61/2) reported in the MSCA manual (McCarthy, 1970, 1972). The .68 correlation of the Binet IV and the MSCA composite scores was slightly higher than the .59 correlation of Binet IV composite SAS and the Wechsler Preschool and Primary Scale of Intelligence Full Scale IQs, which was found using the same sample of kindergarten children (Carvajal, Hardy, Smith, \& Weaver, 1988).

Because of the homogeneity of the subjects in the current study, the correlation may have been lowered, because small fluctuations in homogeneous groups may negatively affect the magnitude of the relationship.

On the basis of this study, it appears that both tests measure similar constructs and that the relationship between the Binet IV and the MSCA is sufficiently high to warrant the use of Binet IV as a primary evaluative instrument with kindergarten children. As with all new tests, further use in the field will determine its ultimate use.

\section{REFERENCES}

Carvajal, H., Hardy, K., Smith, K., \& Weaver, K. (1988). Relationships between scores on Stanford-Binet IV and Wechsler Preschool and Primary Scale of Intelligence. Psychology in the Schools, 25, 129-131.

MCCARTHY, D. (1970, 1972). Manual for the McCarthy Scales of Children's Abilities. New York: Psychological Corp.

SAlviA, J., \& YsseldYKe, J. (1985). Assessment in special and remedial education (3rd ed.). Boston, MA: Houghton Mifflin.

(Manuscript received for publication November 27, 1987.) 